\title{
ANALISIS PENYELESAIAN TINDAK LANJUT HASIL PEMERIKSAAN BPK PADA PEMERIKSAAN KINERJA ATAS KEGIATAN APIP INSPEKTORAT KABUPATEN BARITO TIMUR
}

\author{
Josmar Lambok Banjar Nahor ${ }^{1}$, Ade Adriani ${ }^{2}$, Wahyudin Nor ${ }^{3}$ \\ Magister Akuntansi Universitas Lambung Mangkurat Banjarmasin \\ zoesbanjar@gmail.com
}

\begin{abstract}
The purpose of this research is to reveal the obstacles in the completion of the follow-up of audit the BPK of the performance audit of APIP Inspectorate of East Barito Regency. This research uses qualitative methods with a case study approach which was carried out at the Inspectorate of Barito Timur, Central Kalimantan from September to December 2018. The result of the analysis reveal that the obstacles in completing this follow-up are caused by several internal aspects, including: 1) human resources, the lack of ASN, the mismatch of the educational background of the ASN personnel, and the lack of teamwork 2) leadership, the leader has not yet prepared a work plan for completion of the follow-up to the BPK audit results on performance audit of APIP activities, formed a special team, coordinates, controls, never holding a special meeting to discuss BPK findings on the completion of the BPK audit follow - up on the performance audit APIP, there is no formation of a special team that handle the completion of the follow-up results of the BPK audit on the performance audit of APIP, there is no instruction from the leadership to complete the follow-up of the BPK audit results on the APIP performance audit. 3) Work environment, non-physical work environment, a work culture that has not been optimal, encourages completion of follow-up. Meanwhile, the physical work environment, such as the availability of facilities and facilities is still limited. Research on these three aspects is very useful to understand how to optimize the acceleration of the completion of the follow-up of the inspection results, especially in the Inspectorate of East Barito Regency APIP
\end{abstract}

Keywords: Follow-up of audit the BPK, Human Resources, Leadership, Work Environment.

\section{PENDAHULUAN}

Pemeriksaan atas pengelolaan keuangan negara perlu dilakukan dalam rangka memastikan apakah keuangan negara yang dikelola pemerintah telah dilaksanakan sesuai dengan ketentuan dan tujuan yang diharapkan. Guna meningkatkan transparansi dan akuntabilitas keuangan negara serta menciptakan tata kelola pemerintahan yang baik dan bersih, maka dibentuklah suatu lembaga negara yang melaksanakan tugas lembaga pemeriksa pengelolaan keuangan negara yaitu BPK.

Setelah BPK melakukan pemeriksaan atas pengelolaan keuangan negara/daerah baik itu merupakan pemeriksaan keuangan, pemeriksaan kinerja dan pemeriksaan dengan tujuan tertentu, selanjutnya menuangkan hasil pemeriksaan tersebut dalam bentuk Laporan Hasil Pemeriksaan (LHP). Bagian akhir dari suatu proses pemeriksaan lapangan yang dilakukan BPK adalah LHP yaitu proses penilaian kebenaran, kepatuhan, kecermatan, kredibilitas, dan keandalan data/informasi mengenai pengelolaan dan tanggung jawab keuangan negara/daerah yang telah dilaksanakan oleh pemerintah. Hasil pemeriksaan yang optimal diharapkan menjadi umpan balik bagi penyelenggara pemerintahan, untuk dapat memperbaiki kekurangan-kekurangan maupun kelemahan-kelemahan yang terjadi pada pemerintah. LHP yang diberikan oleh pemeriksa adalah temuan pemeriksaan yang menggambarkan kondisi yang ada yang tidak sesuai dengan peraturan yang berlaku sehingga menghasilkan sebuah rekomendasi. Rekomendasi merupakan solusi atas temuan yang terjadi atau jawaban untuk menghilangkan sebab yang terjadi, diberikan oleh pemeriksa berdasarkan hasil pemeriksaannya, yang ditujukan kepada orang dan/atau badan yang berwenang untuk melakukan tindakan dan/atau perbaikan, kemudian sampai dengan penyerahan LHP kepada auditan atau pihak entitas yang diperiksa. LHP merupakan akhir audit lapangan dan sekaligus merupakan awal pekerjaan pemeriksa untuk melakukan Pemantauan Tindak Lanjut Hasil Pemeriksaan (PTLHP).

Tindak lanjut (TL) hasil pemeriksaan adalah langkah-langkah yang harus diambil oleh pemeriksa setelah LHP diserahkan kepada pihak entitas terperiksa. Kegiatan untuk mengidentifikasi dan mendokumentasikan kemajuan entitas dalam melaksanakan rekomendasi audit (Rai, 2008). 
Tujuan tindak lanjut pemeriksaan yang lain juga dijabarkan oleh (Murwanto, Rahmadi, Budiarso, \& Ramadhana, 2009), yaitu memastikan bahwa saran/rekomendasi auditor yang dimuat dalam laporan hasil pemeriksaan telah dilaksanakan secara memadai, dan tepat waktu oleh entitas yang diperiksa, mengetahui perkembangan tindak lanjut saran/rekomendasi dalam laporan hasil pemeriksaan lalu yang masih belum selesai, memonitor koreksi yang sudah dilakukan manajemen, serta hasil dan pengaruhnya bagi entitas yang diperiksa, dan memastikan bahwa temuan yang diperoleh dalam pemeriksaan sebelumnya tidak dijumpai lagi dalam pemeriksaan yang sedang dilaksanakan.

Sejak laporan hasil pemeriksaan diserahterimakan, maka batas waktu penyelesaian temuan hasil pemeriksaan BPK adalah 60 (enam puluh) hari kerja. Selanjutnya, dilakukan koordinasi intensif dalam rangka penanganan dan penyelesaian tindak lanjut sehingga dapat diselesaikan sebelum batas waktu yang ditentukan. Apabila rekomendasi hasil pemeriksaan tidak ditindaklanjuti oleh entitas yang diperiksa, maka tidak akan memberikaan manfaat bagi entitas atau manajemen untuk melakukan perbaikan tata kelola. Rekomendasi yang diberikan oleh pemeriksa BPK merupakan jawaban untuk mengatasi sebab yang terjadi atas kondisi yang ada dan sekaligus mengurangi akibat kondisi tersebut. Sehingga rekomendasi yang diberikan harus segera di tindak lanjuti, apabila dibiarkan maka tidak akan terjadi perubahan perbaikan, maka inti dari sebuah pemeriksaan tidak terletak pada berapa jumlah temuan yang diberikan atau rekomendasi yang dibuat, akan tetapi sudah sejauh mana pelaksanaan penyelesaian tindak lanjut hasil pemeriksaan dilakukan oleh entitas, sehingga membawa perubahan perbaikan tata kelola bukan malah terjadi temuan berulang-ulang.

Berdasarkan kondisi yang ada, penyelesaian tindak lanjut temuan hasil pemeriksaan BPK sering lambat dalam penyelesaian temuan, apalagi seiring berjalannya waktu, bahwa pemeriksaan dilakukan tiap tahunnya, apabila tidak ditindaklanjuti, maka akan terjadi penumpukan sisa temuan yang belum selesai, sebagaimana tabel berikut:

\section{Tabel 1. Rekapitulasi Pemantauan Tindak Lanjut Hasil Pemeriksaan BPK}

\begin{tabular}{|c|l|c|c|}
\hline No. & Tahun Pemeriksaan & Temuan & Rekomendasi \\
\hline 1. & Tahun 2016 & 386 & 931 \\
\hline 2. & Tahun 2017 & 397 & 951 \\
\hline
\end{tabular}

Sumber: data diolah 2018

Hal ini disebabkan oleh tindak lanjut hasil pemeriksaan khususnya yang berkaitan dengan administrasi dianggap bukan sesuatu yang penting, padahal temuan-temuan administrasi lebih memberikan rekomendasi untuk perbaikan sistem sehingga tata kelola pemerintahan dapat dicapai dengan baik, disamping temuan yang menyebabkan kerugian negara/daerah yang harus segera menyetor ke kas negara dan daerah.

Berdasarkan LHP BPK RI (BPK-RI, 2013) atas pemeriksaan kinerja pada kegiatan Pemerintah Kabupaten Barito Timur yang diserahkan pada tanggal 30 Desember 2013, bahwa temuan pemeriksaannya merupakan temuan administrasi dengan jumlah 9 (sembilan) temuan dan 9 (sembilan) rekomendasi yang bertujuan untuk memperbaiki sistem khususnya pada Inspektorat Kabupaten Barito Timur. Pemeriksaan kinerja yang dilakukan BPK atas kegiatan APIP bagi Inspektorat yaitu dengan pemeriksaan kinerja ini diharapkan hasil pemeriksaan BPK dapat meningkatkan kapabilitas APIP sehubungan dengan peran APIP yang sangat strategis dalam rangka meningkatkan mutu laporan keuangan dan mendeteksi atau meminimalkan adanya penyimpangan pengelolaan keuangan maupun kebijakan. APIP mempunyai peran yang sangat penting dalam pencapaian tujuan organisasi. Pemeriksaan kinerja atas kegiatan APIP bagi manajemen yaitu pemeriksaan APIP diperlukan untuk memperkuat fungsi pengawasan. Dengan demikian diharapkan dapat memperbaiki tata kelola pemerintahan, transparansi pengelolaan keuangan dan mencegah kecurangan yang mungkin terjadi. Inspektorat diperkuat dan diperbaiki kinerjanya dalam peningkatan akuntabilitas pengelolaan keuangan yang menjadi tanggung jawab kepala daerah kepada DPRD dan masyarakat luas. Unit-unit SKPD dapat didorong oleh Inspekorat untuk meningkatkan akuntabilitas keuangan dan pelayanan publik. Hal ini sangat membantu kepala daerah dalam melaksanakan program dan tugas-tugasnya.

Pemeriksaan yang dilakukan BPK adalah pemeriksaan kinerja atas kegiatan APIP pada Pemerintah Kabupaten Barito Timur sampai dengan periode semester I Tahun 2017 (BPK-RI, 2018) hanya sebesar $33 \%$ dengan status TL telah sesuai atau $67 \%$ belum sesuai dengan rekomendasi.

Rincian temuan pemeriksaan Auditor BPK untuk kategori belum ditindaklanjuti dan belum sesuai ditindaklanjuti terdiri dari: 
a. Kategori belum di tindak lanjuti yaitu:

1. Pedoman kerja Inspektorat Kabupaten Barito Timur belum memadai dengan rekomendasi menginstruksikan Inspektur menyusun Juklak/Juknis/SOP SPIP, program pengawasan, kode etik dan piagam audit intern (Internal Audit Charter).

2. Kegiatan monitoring dan evaluasi yang dilakukan oleh Inspektorat Kabupaten Barito Timur belum memadai dengan rekomendasi menginstruksikan Inspektur menyusun SOP kegiatan monitoring dan evaluasi atas kegiatan pengawasan Inspektorat.

b. Kategori belum sesuai di tindak lanjut yaitu:

1. Inspektorat Kabupaten Barito Timur belum mempunyai regulasi dan kebijakan tentang hubungan kerja pengawasan, kegiatan audit dan reviu laporan keuangan serta kegiatan monitoring dan evaluasi yang memadai.

2. Sumber daya pendukung Inspektorat Kabupaten Barito Timur belum memadai.

3. Hubungan kerja pengawasan Inspektorat Kabupaten Barito Timur belum memadai.

4. Pelaporan audit dan reviu LK pada Inspektorat Kabupaten Barito Timur belum memadai.

Fenomena penyelesaian tindak lanjut hasil pemeriksaan BPK pada pemeriksaan kinerja atas kegiatan APIP Inspektorat Kabupaten Barito Timur menunjukkan persentase penyelesaian tindak lanjut yang rendah. Hal ini terlihat pada masih adanya rekomendasi yang belum sesuai atau dalam proses tindak lanjut dan belum ditindaklanjuti. Rendahnya penyelesaian tindak lanjut hasil LHP BPK pemeriksaan kinerja atas kegiatan APIP pada Pemerintah Kabupaten Barito Timur ini dapat menjadi gambaran bahwa APIP Inspektorat selaku objek yang terperiksa, belum juga sepenuhnya melaksanakan tindak lanjut atas rekomendasi yang diberikan pemeriksa. Mengingat peran strategis APIP yang melakukan audit terhadap pengelolaan keuangan pemerintah atau berperan sebagai deteksi dini sebelum dilakukan pemeriksaan eksternal oleh BPK. Disamping itu APIP juga merupakan institusi yang mempunyai tupoksi melakukan koordinasi penyelesaian tindak lanjut bagi SKPD sebelum disampaikan kepada pihak yang melakukan pemeriksaan, dalam hal ini berarti sebelum disampaikan kepada BPK. APIP Inspektorat sudah seharusnya menjadi garda terdepan atau contoh bagi semua SKPD di lingkungan pemerintahan baik dalam tata kelola pemerintahan termasuk dalam hal penyelesaian tindak lanjut hasil pemeriksaan BPK.

Peneliti melakukan telaah pustaka terkait penyelesaian tindak lanjut hasil pemeriksaan. Peneliti menemukan penelitian yang dilakukan oleh (Lusiana, Djamhuri, \& Prihatiningtias, 2017) tentang analisis penyelesaian tindak lanjut hasil pemeriksaan yang menyimpulkan bahwa OPD di Pemerintah Kabupaten Sanggau telah melaksanakan proses penyelesaian TLHP dengan melaksanakan setiap tahapan/fungsi manajemen sebagai respon dari rekomendasi hasil pemeriksaan BPK. Hasil penelitian menemukan bahwa terdapat kelemahan dalam proses penyelesaian TLHP yang dilakukan Pemerintah Kabupaten Sanggau yang menyebabkan belum optimalnya penyelesaian TLHP. Penelitian dilakukan oleh (Harinurhady, Rifa'i, \& Alamsyah, 2017) tentang Analisis Penyelesaian TLHP Auditor Inspektorat Kabupaten Sumbawa Barat. Kendala utama penyebab masih adanya temuan yang tidak dan atau belum selesai ditindaklanjuti adalah kurangnya komunikasi, masih kurangnya Sumber Daya Manusia, komitmen kepala/pimpinan SKPD, melibatkan semua komponen organisasi. Penelitian (Pangoliu, Saerang, \& Manossoh, 2017) tentang analisis kendala penyelesaian TLHP BPK pada pemerintah Provinsi Gorontalo yang menyimpulkan bahwa kendala-kendala yang dihadapi SKPD Provinsi Gorontalo dalam penyelesaian tindak lanjut hasil pemeriksaan BPK adalah pejabat belum sepenuhnya berkomitmen, lemahnya pengendalian internal SKPD, pihak terkait temuan sudah mutasi/pensiun/meninggal dunia, pengembalian kerugian Negara/Daerah belum dilaksanakan secara maksimal, rotasi pegawai dan adanya ketidaksepakatan atas hasil pemeriksaan.

Fenomena rendahnya tingkat penyelesaian tindak lanjut hasil pemeriksaan BPK pada pemeriksaan kinerja atas kegiatan APIP Kabupaten Barito Timur serta berbagai temuan penelitian terdahulu melatarbelakangi untuk dilakukan penelitian yang bertujuan untuk menganalisis penyelesaian tindak lanjut hasil pemeriksaan BPK pada pemeriksaan kinerja atas kegiatan APIP Inspektorat Kabupaten Barito Timur. 


\section{TINJAUAN PUSTAKA Teori Keagenan}

Konsep agency theory menurut (Jensen \& Meckling, 1976) mendefinisikan hubungan keagenan sebagai sebuah kontrak dimana satu atau lebih (principal) menyewa orang lain (agent) untuk melakukan beberapa jasa untuk kepentingan mereka dengan mendelegasikan beberapa wewenang pembuatan keputusan kepada agent. Menurut (Halim \& Abdullah, 2006) teori prinsipal-agent menganalisis susunan kontraktual di antara dua atau lebih individu, kelompok, atau organisasi. Salah satu pihak (principal) membuat suatu perikatan kerja dengan pihak lain (agent), dengan harapan bahwa pihak agent akan melaksanakan pekerjaan yang diberikan oleh prinsipal sesuai dengan yang diinginkan oleh prinsipal sebagai pemberi delegasi.

Dilihat dalam konteks Pemerintahan Daerah, bahwa teori keagenan ini merupakan hubungan antara prinsipal masyarakat yang diwakilkan kepada DPRD (legislatif) dan pihak pemerintah (eksekutif) sebagai pihak agent. Prinsipal memberikan kewenangan kepada pemerintah sebagai agent, dan memberikan dukungan sumberdaya dalam bentuk APBD sebagai sarana untuk melaksanakan pengelolaan pemerintahan yang baik sehingga tercapai tujuan yang diharapkan yaitu masyarakat yang sejahtera. Sebagai bentuk pertanggungjawaban pihak agent (eksekutif) akan memberikan pertanggungjawaban atas pengelolaan APBD yang telah disetujui oleh prinsipal, akan memberikan laporan penggunaan anggaran tersebut dalam bentuk laporan pertanggungjawaban seperti halnya laporan keuangan pemerintah daerah, laporan pertanggungjawaban pemerintah daerah, laporan kinerja pemerintah daerah yang dipertanggungjawabkan setiap tahunnya. Salah satu bentuk pertanggungjawaban pemerintah dalam pelaksanaan APBD adalah Laporan Keuangan Pemerintah Daerah (LKPD) setiap Berdasarkan teori keseimbangan yang dibahas oleh (Herbert, 2005) dalam buku Auditing the Performance of Management, bahwa ada tiga pihak saling berkaitan dalam kegiatan pemeriksaan yaitu pihak pemeriksa BPK, entitas yang diperiksa yaitu pemerintah sebagai yang melaksanakan anggaran dan pihak DPR/DPRD selaku yang meminta pertanggungjawaban kepada pemerintah atas pengelolaan anggaran. Pihak pertama sebagai pemeriksa BPK adalah pihak yang melaksanakan pemeriksaan akuntabilitas pertanggungjawaban pihak kedua selaku pemerintah dan memberikan atestasi kepada berakhirnya tahun anggaran, maka pemerintah (eksekutif) segera menyusun LKPD tersebut. Laporan tersebut terdiri dari LRA, LPSAL, LO, LPE, LAK, Neraca, CaLK serta bentuk penyajiannya harus mengacu pada Standar Akuntansi Pemerintah. Laporan keuangan ini merupakan laporan pertanggungjawaban pemerintah (agent) atas pelaksanaan APBD yang telah diterima dalam satu tahun. Pemerintah wajib melaksanakan pengelolaan keuangan daerah secara tertib, sesuai dengan peraturan perundangundangan yang berlaku dan transparan,

Untuk menguji pelaksanaan APBD tersebut, berdasarkan peraturan yang berlaku, maka laporan keuangan pemerintah daerah tersebut akan diaudit oleh Badan Pemeriksa Keuangan setiap tahunnya. Jenis kegiatan pemeriksaan BPK terdiri pemeriksaan keuangan yaitu pemeriksaan atas LKPD untuk memberikan opini atas kewajaran yang disajikan dalam LKPD. Pemeriksaan kinerja yaitu pemeriksaan untuk menguji aspek ekonomi, efisiensi dan efektifitas dalam rangka perbaikan manajemen pemerintahan. Kemudian pemeriksaan dengan tujuan tertentu yaitu pemeriksaan khusus atau lebih sering disebut pemeriksaan investigasi atau pemeriksaan atas adanya dugaan tindak pidana korupsi.

Setelah BPK melakukan kegiatan pemeriksaan atas pelaksanaan APBD tersebut yang dituangkan dalam bentuk laporan hasil pemeriksaan (LHP). Maka pihak pemerintah (agent) melaksanakan tindak lanjut hasil pemeriksaan (TLHP). BPK mengharapkan rekomendasi hasil pemeriksaannya terhadap lembaga negara ataupun pemerintah dapat segera ditindaklanjuti sehingga pengelolaan keuangan negara/daerah dapat semakin baik. Efektivitas hasil pemeriksaan BPK akan tercapai jika laporan hasil pemeriksaannya ditindaklanjuti oleh entitas yang diperiksa. Selanjutnya BPK akan melakukan pemantauan secara periodik atas pelaksanaan tindak lanjut rekomendasi hasil pemeriksaan yang telah dilaksanakan oleh pemerintah (agent).

\section{Teori Keseimbangan}

DPR/DPRD selaku pihak ketiga. Pihak kedua pemerintah adalah entitas yang bertanggung jawab kepada pihak ketiga dan diperiksa akuntabilitasnya oleh pihak pertama. Pihak ketiga DPR/DPRD sebagai penerima akuntabilitas dan hasil audit adalah entitas yang menerima pertanggungjawaban dari pemerintah selaku pihak kedua dan menerima laporan hasil pemeriksaan dari BPK selaku pihak pertama (Rai, 2008, p. 28).

Pemeriksaan erat kaitannya dengan akuntabilitas pelaksanaan anggaran oleh pemerintah. Akuntabilitas berkaitan dengan kewajiban dari pihak pemerintah untuk 
melaporkan pertanggungjawabannya atas pengelolaan anggaran kepada pihak BPK selaku pemeriksa dari eksternal atau sebagai lembaga yang independen melakukan pemeriksaan. Hubungan kegiatan pemeriksaan dikaitkan dengan sistem pemerintahan di Indonesia, maka yang berperan sebagai pihak pertama adalah pemeriksa eksternal pemerintah yaitu BPK, pihak kedua (auditee) pemerintah pusat $\mathrm{K} / \mathrm{L}$, pemerintah daerah dan pihak ketiga adalah DPR/DPRD seperti terlihat dalam gambar berikut ini.

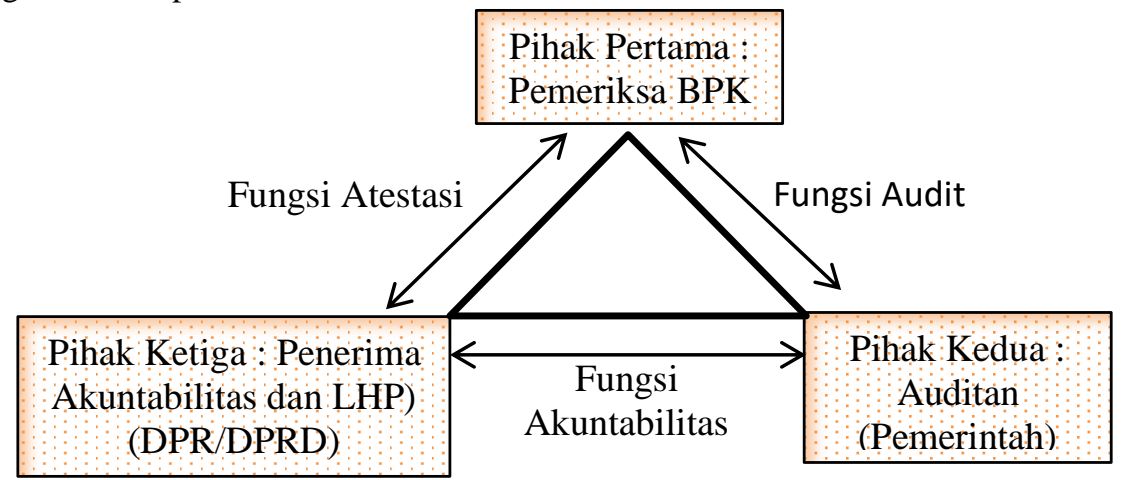

Gambar 1 Hubungan Tiga Pihak dalam Kegiatan Pemeriksaan

\section{Tindak Lanjut Hasil Pemeriksaan}

Tindak lanjut hasil pemeriksaan adalah langkah-langkah yang harus diambil oleh pemeriksa setelah LHP diserahkan kepada pihak entitas terperiksa. Kegiatan untuk mengidentifikasi dan mendokumentasikan kemajuan entitas dalam melaksanakan rekomendasi audit (Rai, 2008). Secara umum, tujuan utama dari tindak lanjut pemeriksaan adalah untuk meningkatkan efektivitas dan dampak dari laporan pemeriksaan. Secara spesifik tujuan dari tindak lanjut adalah sebagai berikut:

1. membantu pihak eksekutif dalam mengarahkan tindakan yang akan diambil terkait dengan hasil pemeriksaan yang diterimanya;

2. mengevaluasi kinerja lembaga pemeriksaan itu sendiri. Hasil tindakan pemeriksaan dapat menjadi ukuran yang baik untuk menilai dan mengevaluasi kinerja lembaga pemeriksaan, seperti menilai tingkat kehematan pelaksanaan pemeriksaan;

3. memberikan masukan bagi perencanaan strategis pemeriksaan bagi lembaga pemeriksaan. Dengan adanya tindak lanjut, auditor dapat melakukan perbaikan atas perencanaan pemeriksaan di masa mendatang; dan

4. mendorong pembelajaran dan pengembangan auditi. Kegiatan tindak lanjut diharapkan dapat memberikan kontribusi bagi perbaikan pelaksanaan kegiatan auditi.

Pekerjaan pemeriksaan dapat dikatakan efektif apabila rekomendasi yang didasarkan atas temuan pemeriksaan telah ditindaklanjuti oleh pihak entitas terperiksa. Sumber daya yang telah dikorbankan untuk pelaksanaan tugas pemeriksaan akan menjadi siasia apabila pada akhirnya rekomendasi tidak ditindaklanjuti sehingga permasalahan masih tetap terjadi. Suatu pemeriksaan dikatakan efektif sangat ditentukan oleh kecepatan dan ketepatan pelaksanaan tindak lanjut hasil pemeriksaan

\section{Sumber Daya Manusia}

Unsur yang tidak bisa diabaikan dalam mendukung kapasitas organisasi adalah sumber daya manusia. Sumber daya manusia dalam organisasi sebagai faktor penggerak organisasi. Akan tetapi dilain pihak sumber daya manusia dalam sebuah organisasi tidak hanya dipahami sebagai individu-individu akan tetapi merupakan sebuah tim kerja (teamwork) baik dalam sebuah organisasi publik maupun swasta. Menurut (Robbins \& Judge, 2007) mengemukakan bahwa karakteristik sebuah teamwork adalah memiliki tujuan bersama, bersinergi secara positif, akuntabilitas secara pribadi maupun mutual, dan adanya keahlian (skill) yang bersifat komplementer diantara sesama anggotanya. Model tim kerja yang efektif terbentuk dari beberapa unsur yaitu konteks, komposisi, desain kerja dan proses.

Menurut (Notoatmodjo \& Soekidjo, 2009) Sumber daya manusia dapat dilihat dari dua aspek yaitu aspek kualitas dan kuantitas. Kuantitas menyangkut sumber daya manusia kurang penting kontribusinya dalam pembangunan, dibandingkan dengan aspek 
kualitas. Bahkan kuantitas sumber daya manusia tanpa disertai dengan kualitas yang baik akan menjadi beban pembangunan suatu bangsa. Meningkatkan kualitas sumber daya manusia, diperlukan peningkatan pendidikan dan pelatihan untuk pengembangan sumber daya manusia.

$$
\text { Selanjutnya menurut (Nawawi, }
$$

Manajemen Sumber Daya Manusia, 2001) sumber daya manusia didefinisikan menjadi tiga pengertian yaitu (1) manusia yang bekerja dilingkungan suatu organisasi (disebut juga personil, tenaga kerja/karyawan); (2) potensi manusia sebagai penggerak organisasi dalam mewujudkan tujuannya; (3) potensi sebagai aset dan yang berfungsi sebagai modal organisasi yang dapat mewujudkan potensi nyata secara fisik dan non fisik.

Sumber daya manusia merupakan faktor yang penting dalam menuju misi dan tujuan serta pencapaian hasil suatu organisasi, sebab tanpa adanya sumber daya manusia, proses yang terjadi dalam organisasi tidak akan dapat berjalan dengan baik.

\section{Kepemimpinan}

Para ahli memberikan definisi kepemimpinan, antara lain menurut (Tannebaum \& Nassarik, 1961) kepemimpinan adalah pengaruh antar pribadi yang dijalankan dalam suatu situasi tertentu, serta diarahkan melalui proses komunikasi, ke arah satu atau beberapa tujuan tertentu. Menurut (CF.Rauch \& Behling, 1984) kepemimpinan adalah proses mempengaruhi kegiatan suatu kelompok dalam organisasi untuk pencapaian tujuan. Menurut (Jacobs \& Jaques, 1990) kepemimpinan adalah suatu proses memberi arti penting terhadap usaha bersama dan yang mengakibatkan kesediaan melakukan kegiatan yang diingankan dalam rangka pencapaian tujuan.

Selanjutnya (Thoha \& Miftah, 2009) merumuskan kepemimpinan adalah kegiatan untuk mempengaruhi perilaku orang lain atau mempengaruhi perilaku manusia baik perorangan atau kelompok. Kemudian mengatakan bahwa upaya mempengaruhi perilaku individu tersebut hanya akan efektif jika seorang pemimpin mampu memainkan peran interpersonal, informasional dan decisional. Menurut (Effendy, 2011) fungsi kepemimpinan ialah memandu, menuntun, membimbing, membangun, memberi motivasi kerja, mengarahkan organisasi, menjalin jaringan komunikasi yang baik, memberikan pengawasan yang efisien, dan membawa para anggotanya untuk mencapai tujuan yang telah direncanakan sebelumnya.

Menurut (Badu \& Djafri, 2017) pemimpin adalah individu yang memimpin, dan kepemimpinan merupakan sifat yang harus dimiliki seorang pemimpin. Oleh karena itu, kepemimpinan adalah upaya untuk mempengaruhi orang lain dengan memberikan dorongan dan bimbingan dalam bekerjasama untuk mengejar tujuan yang telah disepakati bersama. Keberhasilan dalam usaha pencapaian tujuan yang telah ditentukan sangat ditentukan oleh kemampuan seorang pemimpin, yang mempunyai peranan yang sangat penting dalam rangka menggerakkan bawahannya. Keterampilan pemimpin (leadership skill) yang baik dan efektif sangat berpengaruh untuk membangun, mendorong dan menghasilkan kualitas pekerjaan sehingga meraih keberhasilan organisasi. Oleh karena itu, keahlian dalam memimpin sangat dibutuhkan untuk meningkatkan efisiensi dan mencapai tujuan organisasi. Berdasarkan definisidefinisi tersebut, dapat disimpulkan bahwa kepemimpinan adalah upaya untuk mempengaruhi orang lain dengan memberikan dorongan dan bimbingan dalam bekerjasama untuk mengejar tujuan yang telah disepakati bersama.

\section{Lingkungan Kerja}

Menurut (Sedarmayanti, 2009) menjelaskan bahwa lingkungan kerja adalah keseluruhan alat perkakas dan bahan yang dihadapi, lingkungan sekitarnya dimana seseorang bekerja, metode kerja, serta pengaturan kerjanya baik sebagai perseorangan maupun sebagai kelompok. Menurut (Sedarmayanti, 2009) lingkungan kerja terbagi 2 (dua) bagian yaitu lingkungan kerja fisik dan lingkungan kerja non fisik. Lingkungan kerja fisik adalah semua yang berkaitan dengan keadaan berbentuk fisik yang ada lingkungan tempat kerja yang dapat mempengaruhi karyawan baik secara langsung maupun tidak langsung, diantaranya seperti halnya bagaimana dengan suhu udara di ruangan, sirkulasi udara, sistem pencahayaan, kebisingan dari sekitar, bau tidak sedap dari lingkungan sekitar dan bentuk fisik lainnya. Sementara lingkungan kerja non fisik adalah hubungan kerja yang berkaitan dengan antara pimpinan dengan bahwahan dan hubungan antar sesama bawahan.

Menurut (Suwatno \& Priansa, 2011) secara umum lingkungan kerja terdiri dari lingkungan kerja fisik dan lingkungan kerja psikis. Faktor lingkungan kerja fisik adalah lingkungan yang berada disekitar pekerja itu sendiri. Kondisi dilingkungan kerja dapat mempengaruhi kepuasan kerja karyawan yang meliputi rencana ruang kerja, rancangan pekerjaan, kondisi lingkungan pekerjaan, tingkat keleluasaan pribadi (visual privacy) dan pendengaran (acoustical privacy). Lingkungan kerja psikis adalah hal-hal yang menyangkut dengan hubungan sosial dalam organisasi. Lingkungan kerja fisik dan lingkungan kerja 
psikis, keduanya sama pentingnya dalam sebuah organisasi, kedua lingkungan kerja ini tak bisa dipisahkan.

Menurut para ahli menjelaskan tentang definisi budaya kerja diantaranya (Nawawi, Manajemen Sumber Daya Manusia, 2003) budaya kerja adalah kebiasaan yang dilakukan berulangulang oleh pegawai dalam suatu organisasi, pelanggaraan terhadap kebiasaan ini memang tidak ada sanksi tegas, namun dari pelaku organisasi secara moral telah menyepakati bahwa kebiasaan tersebut merupakan kebiasaan yang harus ditaati dalam rangka pelaksanaan pekerjaan untuk mencapai tujuan.

Berdasarkan berbagai pendapat tersebut diatas maka yang dimaksud dengan faktor lingkungan kerja adalah tingkat keberhasilan pegawai/karyawan dalam mengantisipasi pengaruh lingkungan kerja baik itu fisik dan non fisik, dari luar (eksternal) maupun dari dalam (internal) terhadap perubahan nilai yang mempengaruhi kinerja organisasi.

\section{Penelitian Terdahulu}

Penelitian dilakukan oleh (Lusiana, Djamhuri, \& Prihatiningtias, 2017) tentang analisis penyelesaian tindak lanjut hasil pemeriksaan yang menyimpulkan bahwa OPD di Pemerintah Kabupaten Sanggau telah melaksanakan proses penyelesaian TLHP dengan melaksanakan setiap tahapan/fungsi manajemen sebagai respon dari rekomendasi hasil pemeriksaan BPK. Hasil penelitian menemukan bahwa terdapat kelemahan dalam proses penyelesaian TLHP yang dilakukan Pemerintah Kabupaten Sanggau yang menyebabkan belum optimalnya penyelesaian TLHP. Kelemahankelemahan yang ditemukan peneliti, yaitu:

1. Belum tersedianya kebijakan khusus tentang TLHP sehingga para pelaksana tidak memiliki panduan dalam pelaksanaan kegiatan.

2. Lambatnya respon pihak lain dalam pelaksanaan proses koordinasi dan belum intensifnya koordinasi antara OPD dan lembaga pengawasan.

3. Pimpinan belum mampu memberikan motivasi kepada para pegawai dalam melakukan penyelesaian TLHP.

4. Kurangnya komitmen pimpinan yang terlihat dari kebijakan mutasi pegawai yang tidak mempertimbangkan kewajiban TLHP yang belum selesai.

5. Kesulitan dalam melakukan proses evaluasi dan evaluasi yang tidak dilaksanakan secara berkala.
6. Belum optimalnya peran Majelis Pertimbangan TPTGR dalam menangani kasus kerugian daerah.

7. Belum optimalnya penyelesaian TLHP disebabkan oleh kendala-kendala teknis yang dihadapi oleh OPD. Penelitian dilakukan oleh

(Harinurhady, Rifa'i, \& Alamsyah, 2017) tentang Analisis Penyelesaian TLHP Auditor Inspektorat Kabupaten Sumbawa Barat. Kendala utama penyebab masih adanya temuan yang tidak dan atau belum selesai ditindaklanjuti adalah:

1. Kurangnya komunikasi yang baik di tingkatan Manajemen SKPD pada Kabupaten Sumbawa Barat.

2. Masih kurangnya Sumber Daya Manusia (SDM) yang kompeten.

3. Komitmen kepala/pimpinan SKPD dalam penyelesaian TLHP.

4. Melibatkan semua komponen organisasi dalam penyelesaian TLHP.

Penelitian (Pangoliu, Saerang, \& Manossoh, 2017) tentang analisis kendala penyelesaian TLHP BPK pada pemerintah Provinsi Gorontalo yang menyimpulkan bahwa kendala-kendala yang dihadapi SKPD Provinsi Gorontalo dalam penyelesaian tindak lanjut hasil pemeriksaan BPK adalah:

1. Pejabat/ASN terkait temuan belum sepenuhnya berkomitmen terhadap penyelesaian tindak lanjut hasil pemeriksaan BPK.

2. Lemahnya pengendalian internal SKPD.

3. Pihak terkait temuan sudah mutasi/pensiun/meninggal dunia dan yang terkait dengan pihak ketiga yaitu perusahaan telah non aktif serta alamat tidak diketahui lagi.

4. Pengembalian kerugian negara/daerah belum dilaksanakan secara maksimal oleh SKPD.

5. Rotasi pegawai pada Pemerintah Provinsi Gorontalo berdampak pada kelambanan penanganan tindak lanjut hasil pemeriksaan BPK.

6. Adanya ketidaksepakatan atas hasil pemeriksaan yang berdampak pada berlarutlarutnya temuan yang tidak dapat ditindaklanjuti karena penghapusan temuan oleh BPK harus melalui proses yang cukup lama.

\section{METODOLOGI PENELITIAN}

Desain penelitian ini menggunakan format deskriptif kualitatif. Menurut (Bungin, Penelitian Kualitatif, 2015) penelitian deskriptif 
kualitatif bertujuan untuk menggambarkan, meringkaskan berbagai kondisi, berbagai situasi, atau berbagai fenomena realitas sosial yang ada di masyarakat yang menjadi objek penelitian, dan berupaya menarik realitas itu kepermukaan sebagai suatu ciri, karakter, sifat, model, tanda, atau gambaran tentang kondisi, situasi, ataupun fenomena tertentu.

Penelitian ini menggunakan peneliti sebagai key instrument penelitian yaitu dengan melakukan wawancara atau percakapan langsung peneliti dengan narasumber yang langsung menangani penyelesaian TLHP di Inspektorat Kabupaten Barito Timur. Wawancara ini dimaksudkan untuk mengungkapkan fakta yang terjadi dalam proses penyelesaian TLHP. Teknik wawancara yang digunakan adalah wawancara terbuka (open interview) dengan maksud agar responden mengetahui bahwa mereka sedang diwawancarai dan mengetahui maksud dan tujuan wawancara. Peneliti akan menggunakan pedoman wawancara (interview guide) yang merupakan penuntun bagi peneliti dalam mengembangkan pertanyaan-pertanyaan yang bersifat terbuka sehingga memberikan kebebasan yang seluasluasnya bagi responden untuk menyampaikan pendapatnya.

Jenis data yang dikumpulkan dalam penelitian ini adalah data primer dan data sekunder. Data primer diperoleh dengan menggunakan metode wawancara. Wawancara dilakukan kepada pejabat yang mempunyai kaitan langsung dengan penyelesaian TLHP-BPK pemeriksaan kinerja atas kegiatan APIP Inspektorat Kabupaten Barito Timur adalah pejabat struktural yang terdiri dari Inspektur, Sekretaris, Inspektur Pembantu Wilayah I, II, III, Kepala Sub Bagian Administrasi dan Umum, Kasubbag Perencanaan, Evaluasi dan Pelaporan, dan pejabat fungsional Auditor APIP yang menangani penyelesaian tindak lanjut hasil pemeriksaan BPK.

Data sekunder diperoleh dengan cara observasi dan dokumentasi. Data sekunder dalam penelitian ini berupa penelusuran dokumendokumen yang berkaitan dengan proses penyelesaian TLHP yang terdiri dari LHP, Laporan TLHP serta Laporan Tahunan Inspektorat Kabupaten Barito Timur atas penyelesaian tindak lanjut hasil pemeriksaan serta referensi lainnya yang berkaitan dengan obyek dan topik yang diteliti.

Metode analisis data yang digunakan dalam penelitian ini, dengan melakukan analisis data yang telah dikumpulkan dari lapangan. Teknik analisis yang digunakan adalah analisis deskriptif kualitatif. Melalui teknik ini akan digambarkan seluruh data atau fakta yang diperoleh dengan mengembangkan kategori yang relevan dengan tujuan penelitian dan penafsiran terhadap hasil analisis deskriptif dengan berpedoman pada teori-teori yang sesuai.

Selanjutnya analisis data ini akan dilakukan secara induktif yakni penganalisisan dengan cara menarik kesimpulan atas data yang berhasil dikumpulkan dari yang berbentuk khusus ke bentuk umum atau penalaran untuk mencapai suatu kesimpulan mengenai semua unsur unsur penelitian mengenai analisis faktor-faktor internal Inspektorat yang menjadi hambatan dalam penyelesaian TLHP pada pemeriksaan kinerja atas kegiatan APIP Inspektorat Kabupaten Barito Timur.

\section{HASIL PENELITIAN DAN PEMBAHASAN}

Penelitian ini fokus pada aspek internal dalam melaksanakan penyelesaian tindak lanjut yaitu (1) sumber daya manusia, (2) kepemimpinan dan (3) lingkungan kerja.

Aspek sumber daya manusia dan perannya dalam penyelesaian tindak lanjut

Berdasarkan hasil wawancara, observasi dan dokumen data sekunder mengungkap bahwa sumber daya manusia aspek kuantitas (jumlah) pada APIP Inspektorat Kabupaten Barito Timur masih belum mencukupi. Kuantitas personil Inspektorat secara keseluruhan baik fungsional maupun sebagai pelaksana di Sekretariat Inspektorat juga masih belum mencukupi. Pejabat fungsional auditor pada APIP Inspektorat Kabupaten Barito Timur hanya berjumlah 12 (dua belas) orang, atau secara keseluruhan Pegawai Negeri Sipil yang ada hanya 31 (tiga puluh satu) orang, yang akan berimplikasi terhadap tumpukan beban kerja pekerjaan kepada masing-masing personil yang ada.

Secara tugas bahwa APIP Inspektorat Kabupaten Barito Timur harus menindaklanjuti semua LHP-BPK RI, LHP-BPKP, LHP Inspektorat Provinsi Kalimantan Tengah dan LHP Inspektorat Kabupaten Barito Timur. Disamping menindaklanjuti LHP, tugas utamanya adalah melaksanakan quality assurance melalui tugas pengawasan seperti audit, reviu, pemeriksaan khusus dan kegiatan tambahan lainnya, serta consulting yaitu menjalankan fungsi konsutansi seperti menjadi narasumber dalam kegiatan sosialisasi atau dalam pertemuan SKPD.

Aspek kualitas sumber daya manusia yang ada pada Inspektorat Kabupaten Barito Timur dapat dibedakan berdasarkan tingkat pendidikan dan kompetensi masing-masing ASN. Hasil Penelitian menjelaskan bahwa jika dilihat dari segi tingkat pendidikan APIP Inspektorat Kabupaten Barito Timur sebenarnya sudah memadai, karena pegawai ASN di Inspektorat Kabupaten Barito Timur yang berlatar belakang Pascasarjana (S2) sebanyak 9 (sembilan) orang, sarjana (S1) sebanyak 16 (enam belas) orang, 
diploma sebanyak 2 (dua) orang dan SMA/sederajat sebanyak 3 (tiga) orang dan SLTP sebanyak 1 (satu) orang, sehingga total PNS berjumlah 31 (tiga puluh satu) orang.

Kemudian dari aspek kualitas sumber daya manusia yang ada pada Inspektorat Kabupaten Barito Timur apabila dilihat berdasarkan tingkat pendidikan awal masuk di Inspektorat dan pendidikan lanjutan masingmasing ASN. Berdasarkan segi tingkat pendidikan awal di Inspektorat Kabupaten Barito Timur apabila dikelompokkan berdasarkan latar belakang pendidikan. Berdasarkan gambaran latar belakang tingkat pendidikan tersebut diatas ternyata ASN Inspektorat Kabupaten Barito Timur didominasi oleh jurusan Sarjana Ilmu Pemerintahan atau Sarjana Sosial, kemudian urutan berikutnya Sarjana Teknik. Mengingat tugas pokok APIP Inspektorat adalah melakukan audit tata kelola keuangan pemerintah daerah disamping tugas lainnya seperti reviu dan pengawasan lainnya, maka sebaiknya sumberdaya manusia yang ada pada Inspektorat seharusnya dari latar belakang tingkat pendidikan Sarjana Ekonomi khususnya jurusan Akuntansi. Mengingat tugas-tugas APIP Inspektorat tidak semuanya hanya audit keuangan akan tetapi banyak juga tugas-tugas lain diluar tata kelola keuangan, maka tidak menutup kemungkinan ASN Inspektorat berasal dari latar belakang pendidikan lainnya.

Untuk informasi kompetensi ASN Inspektorat, peneliti mendapatkan data penelitian dari admin peningkatan kapabilitas APIP dengan wawancara langsung. Berdasarkan hasil wawancara admin peningkatan kapabilitas APIP, menjelaskan bahwa kompetensi masing-masing auditor telah mengikuti sertifikasi auditor dan mengikuti diklat substansi. Sertifikasi auditor dilaksanakan oleh Pusdiklatwas BPKP sesuai dengan jenjang jabatannya yang dimulai dengan sertifikasi auditor pertama, auditor muda, auditor madya dan auditor utama. Setiap kenaikan jabatan harus lulus ujian sertifikasi. Dalam pelaksanaan tugas masing-masing auditor juga dibekali dengan diklat substansi sesuai dengan jenis kebutuhan dalam melaksanakan tugas jabatan secara profesional dibidang pengawasan. Auditor Madya berjumlah 1 (satu) orang, telah sertifikasi auditor madya, khusus untuk tahun 2018 juga telah mengikuti diantaranya diklat sertifikasi forensik auditor (Certified Forensic Auditor) dan diklat manajemen pengawasan. Auditor Muda sebanyak 4 (empat) orang, telah sertifikasi auditor muda, pada tahun 2018 mengikuti diklat substansi diantaranya diklat peningkatan kapabilitas APIP dan diklat perhitungan angka kredit. Kemudian untuk auditor pertama sebanyak 6 (enam) orang, telah sertifikasi auditor pertama, khusus tahun 2018 mengikuti diklat maturitas SPIP, diklat reviu LKPD berbasis akrual dan diklat penilaian angka kredit. Auditor terampil 1 (satu) orang, telah sertifikasi auditor terampil dan pada tahun 2018 mengikuti diklat substansi diantaranya diklat maturitas SPIP dan diklat peningkatan kapabilitas APIP. Kemudian pejabat struktural juga mengikuti diklat substansi pada Pusdiklatwas BPKP setiap tahunnya minimal 1 (satu) kali dalam setahun, disesuaikan dengan kebutuhan dan dana yang tersedia.

Sesuai dengan teori bahwa sumber daya manusia dalam suatu organisasi sangatlah penting. Sumber daya manusia dapat dilihat dari dua aspek yaitu aspek kuantitas (jumlah) dan kualitas. Kuantitas menyangkut sumber daya manusia kurang penting kontribusinya dalam pembangunan, dibandingkan dengan aspek kualitas. Bahkan kuantitas sumber daya manusia tanpa disertai dengan kualitas yang baik akan menjadi beban pembangunan suatu bangsa (Notoatmodjo \& Soekidjo, 2009). Untuk meningkatkan kualitas sumber daya manusia, maka diperlukan peningkatan pendidikan dan pelatihan untuk pengembangan sumber daya manusia. Maka secara umum pengembangan sumber daya manusia adalah suatu proses peningkatan kualitas atau kemampuan manusia dalam rangka mencapai tujuan organisasi. Sumber daya manusia dalam organisasi sebagai faktor penggerak organisasi.

Berdasarkan gambaran dan kondisi yang ada pada APIP Inspektorat Kabupaten Barito Timur sebenarnya dalam kualitas aspek sumber daya manusia yang ada sudah memadai. Hasil penelitian terkait dengan aspek sumber daya manusia dan perannya dalam penyelesaian tindak lanjut menggambarkan bahwa APIP Inspektorat Kabupaten Barito Timur sebenarnya dalam kualitas aspek sumber daya manusia yang ada sudah memadai, hal ini terlihat dari tingkat pendidikan PNS nya diatas $50 \%$ telah berpendidikan sarjana bahkan ada yang telah pascasarjana. Kemudian dari sisi kompetensinya, dari peta kompetensi juga menggambarkan bahwa Pegawai Negeri Sipil yang ada pada APIP Inspektorat Kabupaten Barito Timur khususnya para auditor juga telah lulus sertifikasi auditor dan juga telah mengikuti diklat-diklat substansi terkait dengan tugas pokok dan fungsi APIP secara rutin setiap tahunnya. 
Pada saat lain sumber daya manusia dalam organisasi tidak hanya dipahami sebagai individu-individu akan tetapi seringkali merupakan sebuah tim kerja (teamwork). Organisasi publik maupun swasta, dituntut untuk memperhatikan eksistensi teamwork. Menurut (Robbins \& Judge, 2007) mengemukakan bahwa karakteristik sebuah teamwork adalah memiliki tujuan kolektif, bersinergi secara positif, akuntabilitas secara pribadi maupun mutual, dan adanya keahlian (skill) yang bersifat komplementer diantara sesama anggotanya. Model tim kerja yang efektif terbentuk dari beberapa unsur yaitu konteks, komposisi, desain kerja dan proses. Kompetensi personil dalam organisasi juga diperlukan baik itu kompetensi teknis, kompotensi manajerial, kompetensi sosial dan kompetensi intelektual. Mengingat sisa temuan BPK tersebut adalah temuan administrasi dengan kategori belum di tindak lanjuti yaitu (1) Pedoman kerja Inspektorat Kabupaten Barito Timur belum memadai dengan rekomendasi menginstruksikan Inspektur menyusun Juklak/Juknis/SOP SPIP, program pengawasan, kode etik dan piagam audit intern (Internal Audit Charter) dan (2) Kegiatan monitoring dan evaluasi yang dilakukan oleh Inspektorat Kabupaten Barito Timur belum memadai dengan rekomendasi menginstruksikan Inspektur menyusun SOP kegiatan monitoring dan evaluasi atas kegiatan pengawasan Inspektorat.

Melihat gambaran temuan tersebut, sangat jelas diperlukan kerjasama tim, pembagian peran, koordinasi dan target sampai kapan penyelesaiannya. Berdasarkan hasil wawancara peneliti, juga menggambarkan bahwa kondisi di APIP Inspektorat Kabupaten Barito Timur, kurangnya kerjasama antar bagian, bidang (team work) atau kerjasama tim termasuk dalam penyelesaian tindak lanjut hasil pemeriksaan BPK atas kinerja APIP Inspektorat Kabupaten Barito Timur. Maka dapat disimpulkan bahwa tanpa kerjasama tim, pembagian peran, koordinasi dan menyusun rencana aksi atas penyelesaian sisa temuan tersebut, akan sulit untuk penyelesaian tindak lanjut hasil pemeriksaan BPK atas pemeriksaan kinerja APIP Inspektorat Kabupaten Barito Timur.

Hasil data penelitian pada aspek sumber daya manusia di Inspektorat Kabupaten Barito Timur, terungkap bahwa:

a. Jumlah sumber daya manusia ASN Inspektorat Kabupaten Barito Timur terungkap belum memadai, sehingga beban kerja masing-masing ASN sangatlah tinggi dalam melaksanakan tugas-tugas pengawasan, sehingga berdampak dalam penyelesaian TLHP BPK atas kinerja APIP.

b. Kualitas sumber daya manusia di unit Inspektorat Kabupaten Barito Timur terungkap sudah memadai apabila dilihat dari tingkat pendidikan, karena dari jumlah pegawai yang ada saat ini sebagian besar sumber daya manusianya adalah pendidikan sarjana, bahkan sudah ada yang berpendidikan pascasarjana.

c. Latar belakang pendidikan ASN Inspektorat Kabupaten Barito Timur didominasi oleh Sarjana Ilmu Pemerintahan atau Sarjana Sosial, sehingga perlu ditambah sumber daya manusia dengan latar belakang pendidikan Sarjana Ekonomi jurusan Akuntansi.

d. Kompetensi sumber daya manusia di unit Inspektorat Kabupaten Barito Timur berdasarkan hasil penelitian terungkap sudah memadai apabila dilihat dari data sekunder yaitu peta kompetensi masing-masing personil ASN yang ada, bahwa telah mengikuti diklat secara rutin setiap tahunnya.

e. Kerjasama tim (teamwork) sumber daya manusia Inspektorat Kabupaten Barito Timur terungkap sangat kurang, masing-masing sumber daya manusia bekerja tanpa adanya kerjasama dalam penyelesaian sisa-sisa tindak lanjut BPK atas kinerja APIP.

\section{Aspek kepemimpinan dan perannya dalam penyelesaian tindak lanjut}

fungsi-fungsi

Kepemimpinan merupakan bagian dari yang menduduki posisi strategis dalam sistem dan hierarki kerja dan tanggung jawab pada sebuah organisasi. Kepemimpinan pada dasarnya merupakan kemampuan seseorang untuk membujuk orangorang lain guna mengambil langkah-langkah dalam mewujudkan visi dan misi organisasi. Kepemimpinan yang bervisi, hanya akan efektif bilamana didukung oleh kemampuan dalam manajerial yang handal. Kemampuan manajerial tersebut meliputi kemampuan dalam merencanakan, mengorganisasikan, mengatur, mengontrol dan mengendalikan sehingga dapat dicapai hasil-hasil sesuai dengan yang diharapkan.

Hasil wawancara menunjukkan bahwa dalam menjalankan tugas Inspektur Kabupaten Barito Timur belum sepenuhnya melaksanakan tugas dan menjalankan peranannya secara optimal sebagai pemimpin APIP khususnya dalam tugas APIP sebagai objek pemeriksaan dari BPK, dimana wajib menindaklanjuti semua temuantemuan yang diberikan BPK dalam LHP. Dalam penyelesaian tindak lanjut hasil pemeriksaan BPK pada pemeriksaan kinerja atas kegiatan APIP, pimpinan belum menyusun rencana kerja penyelesaian sisa temuan, menganggarkan sumber dana, membentuk tim khusus, mengkoordinir, mengontrol dan mengendalikan tim serta menggerakkan bawahan untuk menyelesaikan 
pekerjaan tersebut, sehingga apa yang hasil yang diinginkan dapat tercapai tepat waktu. Inspektur Kabupaten Barito Timur belum sepenuhnya mengarahkan dan mengatur bawahan guna penyelesaian tindak lanjut. Dalam kegiatan manajemen kepemimpinan yang efektif seharusnya mampu mengatur aktifitas anggotanya secara terarah dan dalam koordinasi yang efektif, sehingga memungkinkan tercapainya tujuan bersama secara maksimal.

Menurut (Anaroga \& Panji, 2004), psikolog kepemimpinan yang disebut pemimpin adalah seseorang yang aktif dalam membuat terlaksana, bertugas sebagai koordinator, mengusahakan dan melaksanakan suatu kerja untuk mencapai tujuan bersama. Proses mencapai tujuan organisasi yang telah ditetapkan sangat dibutuhkan peranan seorang pemimpin untuk menggerakkan seluruh fungsi manajemen dan sumber daya yang dimiliki. Menurut (Effendy, 2011) fungsi kepemimpinan ialah memandu, menuntun, membimbing, membangun, memberi motivasi kerja, mengarahkan organisasi, menjalin jaringan komunikasi yang baik, memberikan pengawasan yang efisien, dan membawa para pengikutnya kepada sasaran yang ingin dicapai sesuai dengan target dan perencanaan.

Sebagai institusi yang wajib menindaklanjuti temuan dari berbagai pemeriksa, maka Inspektur selaku pimpinan APIP wajib harus mengetahui sisa temuan yang belum selesai. Melakukan identifikasi permasalahan, menyusun rencana aksi, mengendalikan kegiatan sampai dengan menentukan target penyelesaian. Seharusnya Inspektur memiliki komitmen dan ketegasan dalam penyelesaian tindak lanjut, terlebih lagi Inspektorat sebagai instansi pengawas intern pemerintah yang idealnya menjadi barometer yang baik dalam upaya penyelesaian tindak lanjut. Inspektur harus mampu menggerakkan dan menggugah semangat seluruh sumber daya yang ada sehingga percepatan penyelesaian tindak lanjut dapat tercapai.

Kemudian hasil wawancara peneliti dengan Plh.Kepala Sub Bagian Perencanaan, Evaluasi dan Pelaporan juga menyampaikan bahwa tidak adanya rapat internal di APIP Inspektorat untuk membahas penyelesaian tindak lanjut hasil pemeriksaan BPK atas pemeriksaan kinerja APIP Inspektorat yang belum selesai dengan sampai dengan saat ini. Juga dibuktikan dengan tidak adanya dokumen surat, notulen terkait dengan rapat khusus penyelesaian tindak lanjut pemeriksaan BPK atas pemeriksaan kinerja
APIP. Hal ini menunjukkan bahwa sejauh ini Inspektur belum memuat keputusan yang cepat dan tepat guna penyelesaian tindak lanjut pemeriksaan.

Berdasarkan kondisi tersebut diatas, dari sisi aspek kepemimpinan yang terjadi di APIP Inspektorat Kabupaten Barito Timur tidak sesuai dengan seharusnya pimpinan harus bisa membimbing, membuat struktur, memfasilitasi aktivitas dan hubungan di dalam kelompok atau organisasi, memandu, menuntun, membimbing, membangun, memberi motivasi kerja, mengarahkan organisasi, menjalin jaringan komunikasi yang baik, memberikan pengawasan yang efisien, dan membawa para pengikutnya kepada sasaran yang ingin dicapai sesuai dengan target dan perencanaan.

Pemimpin dalam suatu organisasi harus memiliki kriteria tertentu layaknya seorang pemimpin diantaranya kekuasaan/power; seorang pemimpin umumnya diikuti oleh orang lain karena ia memiliki kekuasaan yang membuat orang lain menghargai keberadaannya. Tanpa kekuasaan atau kekuatan yang dimiliki sang pemimpin tentunya tidak ada orang yang mau menjadi pendukungnya. Kekuasaan dan kekuatan yang dimiliki seorang pemimpin ini menjadikan orang lain akan tergantung pada apa yang dimiliki seorang pemimpin, tanpa itu ia tidak akan bisa berbuat apa-apa. Hubungan ini menjadikan hubungan yang bersifat simbiosis mutualisme, dimana kedua belah pihak merasa saling diuntungkan. Dengan adanya kekuasan/power pimpinan APIP Inspektorat Kabupaten Barito Timur yang mempunyai anggaran dana, sehingga dapat disusun rencana aksi atas penyelesaian temuan BPK.

Berdasarkan dari gaya kepemimpinan, salah satunya gaya kepemimpinan memberitahu. Gaya kepemimpinan memberitahu ini, pemimpin memberikan instruksi khusus dan mensupervisi ketat kinerja para pengikutnya. Memberikan petunjuk secara jelas dan rinci mengenai tugas yang harus dikerjakan para karyawan, mendefinisikan secara operasional peran pengikut, komunikasi sebagian besar satu arah, pemimpin yang membuat keputusan, supervisi ketat dan meminta pertanggungjawaban pengikut dan instruksi secara bertingkat. Hal ini yang tidak dilaksanakan oleh pimpinan APIP, tidak memberikan petunjuk secara jelas dan rinci mengenai tugas yang harus dikerjakan para pegawai dan supervisi ketat dan meminta pertanggungjawaban masing-masing pegawai. 
Terhadap indikator ketauladanan pimpinan APIP Inspektorat Kabupaten Barito Timur menunjukkan bahwa pimpinan mempunyai wibawa dalam mentaati peraturan. Namun pengaruh dan ketauladanan kepemimpinan dalam menggerakkan pegawai untuk penyelesaian tindak lanjut hasil pemeriksaan BPK pada pemeriksaan kinerja atas kegiatan APIP sangat rendah. Hal ini terbukti dari hasil wawancara terungkap bahwa tidak adanya instruksi dari pimpinan untuk menyelesaikan tindak lanjut tersebut.

Pengamatan di lapangan menunjukkan bahwa dalam menjalankan tugas Inspektur Pembantu mempunyai ketauladanan dan kewibawaan, namun yang muncul bukan karena jabatan, tetapi lebih disebabkan hubungan antara personil yang baik. Namun dalam penyelesaian tindak lanjut hasil pemeriksaan BPK pada pemeriksaan kinerja atas kegiatan APIP, Inspektur Pembantu belum mengkoordinir dan menggerakkan bawahan untuk menyelesaikan pekerjaan tersebut, karena tidak adanya perintah dari pimpinan.

Dari uraian diatas menunjukkan bahwa aspek kepemimpinan dalam penyelesaian tindak lanjut di Inspektorat Kabupaten Barito Timur kurang memadai yaitu:

1. Pimpinan belum menyusun rencana kerja penyelesaian tindak lanjut hasil pemeriksaan BPK pada pemeriksaan kinerja atas kegiatan APIP, membentuk tim khusus, mengkoordinir, mengontrol dan pengendalian.

2. Tidak pernah melakukan rapat khusus membahas temuan BPK atas penyelesaian tindak lanjut hasil pemeriksaan BPK atas pemeriksaan kinerja APIP.

3. Tidak ada pembentukan tim khusus yang menangani penyelesaian tindak lanjut hasil pemeriksaan BPK atas pemeriksaan kinerja APIP.

4. Tidak adanya instruksi dari pimpinan untuk penyelesaian tindak lanjut hasil pemeriksaan BPK atas pemeriksaan kinerja APIP.

Aspek lingkungan kerja dan perannya dalam penyelesaian tindak lanjut

Fokus data penelitian pada aspek lingkungan kerja peneliti mengkaji dari dua aspek yaitu aspek lingkungan kerja non fisik dan aspek lingkungan kerja fisik. Menurut (Sedarmayanti, Sumberdaya Manusia dan Produktivitas Kerja, 2009), lingkungan kerja dibagi menjadi 2 (dua) bagian yaitu lingkungan kerja fisik dan lingkungan kerja non fisik. Lingkungan kerja fisik adalah semua keadaan berbentuk fisik yang terdapat disekitar tempat kerja yang dapat mempengaruhi karyawan baik secara langsung maupun tidak langsung. Lingkungan kerja non fisik adalah semua keadaan yang berkaitan dengan hubungan kerja, baik hubungan dengan atasan, maupun hubungan dengan sesama rekan kerja, atau hubungan dengan bawahan. Dalam suatu organisasi lingkungan kerja menurut (Atmosoeprapto, 2002) dipengaruhi oleh faktor internal dan faktor eksternal. Faktor Internal terdiri dari: tujuan organisasi, struktur organisasi, dan sumber daya manusia. Faktor Eksternal terdiri dari faktor politik, faktor ekonomi, faktor sosial.

Faktor lingkungan kerja menjadi penentu perilaku, dimana seseorang akan memberikan reaksi dari setiap aksi yang timbul didalam lingkungannya. Menurut (Robbins \& Judge, 2007) hasil interaksi antara individu dengan lingkungan menghasilkan motivasi. Definisi ini menunjukkan bahwa terdapat keterkaitan antara lingkungan kerja dengan perilaku dan motivasi pegawai dalam melaksanakan tugasnya, sehingga tujuan akhir dari suatu pekerjaan (output) dapat dicapai.

Berdasarkan pengamatan dilapangan dan hasil wawancara terhadap lingkungan kerja aspek fisik bahwa dalam melaksanakan tugas pokok dan fungsi APIP Inspektorat Kabupaten Barito Timur belum sepenuhnya memadai guna menunjang pelaksanaan kinerja yang baik dalam menyelesaian tindak lanjut hasil pemeriksaan BPK atas pemeriksaan kinerja APIP, masih perlu ditunjang dengan tersedianya fasilitas dan sarana untuk melaksanakan pekerjaan. Hal ini sejalan dengan pemahaman bahwa terdapat keterkaitan yang erat antara lingkungan kerja dengan kinerja dan motivasi pegawai. Karena lingkungan kerja yang baik, yaitu tersedianya fasilitas dan sarana akan memudahkan pegawai dalam pelaksanaan tugas-tugasnya.

Terkait dengan aspek lingkungan kerja non fisik di Inspektorat Kabupaten Barito Timur, berdasarkan hasil observasi peneliti yang menjadi permasalahan yaitu budaya kerja pada instansi Inspektorat. Budaya kerja diartikan sebagai sikap dan perilaku individu dan kelompok yang didasari atas nilai-nilai yang diyakini kebenarannya dan telah menjadi sifat serta kebiasaan dalam melaksanakan tugas dan pekerjaan sehari-hari. Sifat dan kebiasaan dalam suatu organisasi berbeda satu dengan yang lainnya, dan sifat atau kebiasaan tersebut menjadi ciri khas organisasi. Melalui sifat dan kebiasaan tersebut dapat diketahui bagaimana karakter suatu organisasi. Budaya kerja merupakan suatu komitmen organisasi, dalam upaya membangun sumber daya manusia, proses kerja, dan hasil kerja yang lebih baik.

Menurut (Sedarmayanti, Sumberdaya Manusia dan Produktivitas Kerja, 2009) budaya kerja dikatakan baik apabila pegawai dapat melaksanakan kegiatannya secara optimal, sehat, aman dan nyaman. Budaya kerja dapat diukur antara lain melalui 1) pengungkapan persyaratan dan petunjuk kerja, 2) mentaati prosedur dan 
instruksi secara tepat, 3) sikap disiplin, 4) tanggung jawab dalam menyelesaikan pekerjaan, dan 5) kebiasaan bekerja sama (Mas'ud, 2004). Manfaat utama dari budaya kerja yang baik yaitu meningkatnya kinerja pegawai.

Inspektorat Kabupaten Barito Timur tentunya memiliki sifat dan kebiasaan yang menjadi karakter atau kekhasannya. Dalam pelaksanaan pekerjaan khususnya penyelesaian tindak lanjut diharapkan sifat dan kebiasaan ini merupakan budaya kerja yang bisa meningkatkan tingkat penyelesaian tindak lanjut hasil pemeriksaan yang sampai saat ini belum terselesaikan.

Hasil observasi peneliti, terhadap budaya kerja di Inspektorat Kabupaten Barito Timur, ditemukan bahwa:

1. Pengungkapan Persyaratan dan Petunjuk Kerja.

Dalam penyelesaian tindak lanjut, pemberian petunjuk atau persyaratan dalam penyelesaian pekerjaan kepada pegawai masih sangat minim. Unsur pimpinan tidak pernah membuat perencanaan, langkahlangkah kerja atau mengarahkan pegawai dalam penyelesaian temuan. Kondisi ini tentunya memperlambat proses penyelesaian tindak lanjut, karena pegawai/staf memiliki keterbatasan pemahaman dalam mencari jalan penyelesaian tindak lanjut. Unsur pimpinan menganggap pegawai sudah mampu mandiri menyelesaikan pekerjaan tersebut. Dengan adanya sifat dan kebiasaan pegawai yang berbeda-beda, terdapat pegawai yang mampu berinisiatif memecahkan permasalahan dan mencari cara dalam penyelesaian pekerjaannya. Namun terdapat pula pegawai yang baru melaksanakan tugas apabila diperintah atasan, artinya pegawai bersifat pasif dan hanya menunggu tanpa adanya upaya inisiatif dalam menyelesaikan pekerjaan. Kondisi ini mengakibatkan proses penyelesaian dalam pekerjaan menjadi lambat.

2. Mentaati Prosedur dan Instruksi Secara Tepat.

Terdapat pegawai yang belum mentaati prosedur dan instruksi secara tepat. Dalam pelaksanaan pekerjaan masih ada sebagian pegawai yang kualitas kerjanya belum sepenuhnya memenuhi standar sesuai prosedur. Terkait penyelesaian tindak lanjut, terdapat pegawai yang meskipun sudah mengetahui cara kerjanya namun dalam implementasinya kurang maksimal. Seperti dalam pengumpulan dokumen pendukung tindak lanjut yang harus memenuhi kriteria cukup, kompeten dan relevan. Dalam pelaksanaannya terkadang masih ada pegawai yang kurang mau mempelajari sungguh-sungguh apakah dokumen pendukung telah memenuhi kriteria dimaksud. Sehingga dalam penyelesaian tindak lanjut bisa terdapat dokumen yang belum memenuhi kriteria sesuai rekomendasi temuan. Tentunya hal ini juga menghambat penyelesaian tindak lanjut. Ketidakpatuhan sebagian pegawai terhadap prosedur pekerjaan merupakan indikasi pegawai belum seluruhnya bersikap profesional.

3. Sikap Disiplin.

Inspektorat Kabupaten Barito Timur berupaya menumbuhkan sikap disiplin pegawai. Seluruh pegawai wajib mengikuti apel pagi jam 7.30 WIB dan apel sore pukul 16.00 WIB, serta wajib mengikuti apel gabungan SKPD pada tanggal 17 setiap bulannya. Selain itu setiap pegawai wajib melakukan absen finger print dan absen manual. Dalam pelaksanaan pekerjaan, upaya penegakkan sikap disiplin ini belum berpengaruh banyak. Karena masih sebagian kecil pegawai yang rajin dan memiliki kesadaran untuk menunaikan kewajiban mengikuti apel pagi dan sore. Teguran yang disampaikan pimpinan berupa teguran lisan kepada pegawai untuk tetap mengikuti apel. Kurang disiplinnya pegawai berdampak pada terhambatnya pekerjaan, seperti ketika pegawai dibutuhkan untuk melakukan suatu pekerjaan, pegawai tersebut tidak ada karena belum datang tepat waktu atau sedang keluar kantor karena urusan lain. Kondisi budaya kerja seperti ini juga berpengaruh terhadap lambatnya proses penyelesaian tindak lanjut.

4. Tanggung Jawab dalam Melaksanakan Pekerjaan.

Tanggung jawab dalam menyelesaikan pekerjaan dengan baik belum sepenuhnya dimiliki oleh seluruh pegawai. Dalam penyelesaian tindak lanjut, tanggung jawab diwujudkan dengan kesadaran akan kewajiban untuk menyelesaikan rekomendasi temuan dan bersungguhsungguh mencari cara penyelesaiannya. Rendahnya rasa tanggung jawab telihat dari sense of belonging atau rasa ikut memiliki dan rasa cinta terhadap kantor Inspektorat 
Kabupaten Barito Timur belum membudaya dan terpatri pada hati setiap pegawainya. Ketika rasa memiliki terhadap institusi sudah ada, maka akan memunculkan rasa tanggung jawab dan pegawai terpacu untuk bersungguh-sungguh dalam bekerja untuk mencapai tujuan Instansi, termasuk menyelesaikan rekomendasi temuan yang masih ada. Rasa tanggung jawab yang kurang dari pihak terkait menyebabkan terhambatnya proses penyelesaian tindak lanjut.

5. Kebiasaan Bekerja Sama.

Dalam penyelesaian tindak lanjut, masih terdapat sikap kurang terbuka dengan rekan kerja untuk melakukan konsultasi dan komunikasi yang berkaitan dengan pelaksanaan kerja. Bekerja sama belum menjadi kebiasaan pada sebagian pegawai Inspektorat Kabupaten Barito Timur. Hal ini disebabkan oleh kurangnya koordinasi antar bidang dalam penyelesaian tindak lanjut hasil pemeriksaan atas pemeriksaan kinerja APIP. Sub Bagian Perencanaan, Evaluasi dan Pelaporan dalam hal ini merupakan bagian yang menangani hal tersebut. Sebagaimana tupoksi dari bagian ini yang diatur dalam (Peraturan Daerah Kabupaten Barito Timur Nomor 3, 2016) dimana terkait dengan tindak lanjut hasil pemeriksaan. Sub Bagian Perencanaan, Evaluasi \& Pelaporan yaitu menginventarisir dan menganalisis hasil pemeriksaan BPK, membantu menyelesaikan tindak lanjut hasil pemeriksaan BPK, merencanakan kegiatan tindak lanjut hasil pengawasan, menyusun jadual pelaksanaan evaluasi laporan hasil pengawasan, menyiapkan, koordinasi dan kerjasama penyelesaian tindak lanjut hasil pemeriksaan dengan aparatur pengawasan BPK, BPKP, Inspektorat Jenderal, Inspektorat Provinsi Kalimantan Tengah dan Inspektorat Kabupaten Barito Timur; dan menyusun data dan informasi yang berkaitan dengan evaluasi dan pelaporan tindak lanjut hasil pemeriksaan. Jika dilihat dari hasil wawancara diatas terlihat bahwa Sub Bagian Perencanaan, Evaluasi \& Pelaporan berjalan dengan sendirinya tanpa adanya koordinasi dengan bidang lain yang melaksanakan pengawasan. Hal ini mengindikasikan kurangnya koordinasi antara bagian dalam melaksanakan penyelesaian tindak lanjut hasil pemeriksaan BPK atas pemeriksaan kinerja pada APIP Inspektorat Kabupaten Barito Timur, yang dibuktikan juga dengan beberapa pernyataan informan.

Budaya kerja berkaitan erat dengan pemberdayaan pegawai. Dalam kaitannya dengan penyelesaian tindak lanjut, terlihat bahwa budaya kerja pada Inspektorat Kabupaten Barito Timur belum dapat membantu menumbuhkan kinerja pegawai untuk menyelesaikan tindak lanjut dengan lebih optimal. Hal ini terlihat dari belum adanya peningkatan motivasi, kreativitas dan semangat kerja pegawai, sehingga selama bertahun-tahun terdapat tindak lanjut yang belum dapat terselesaikan. Setiap pegawai seharusnya memahami tujuan organisasi dan menjalankan peranannya serta memberikan kemampuan terbaiknya dalam mencapai tujuan Instansi.

Berdasarkan pengamatan dilapangan dan hasil wawancara, bahwa lingkungan kerja dapat disimpulkan menjadi:

a. Lingkungan kerja aspek fisik bahwa dalam melaksanakan tugas pokok dan fungsi APIP Inspektorat Kabupaten Barito Timur belum sepenuhnya memadai guna menunjang pelaksanaan kinerja yang baik dalam menyelesaian tindak lanjut hasil pemeriksaan BPK atas pemeriksaan kinerja APIP, masih perlu ditunjang dengan tersedianya fasilitas dan sarana untuk melaksanakan pekerjaan. Hal ini sejalan dengan pemahaman bahwa terdapat keterkaitan erat antara lingkungan kerja dengan kinerja dan motivasi pegawai. Karena lingkungan kerja yang baik, yaitu tersedianya fasilitas dan sarana akan memudahkan pegawai dalam pelaksanaan tugas-tugasnya.

b. Lingkungan kerja aspek non fisik, budaya kerja pada Inspektorat Kabupaten Barito Timur; pengungkapan persyaratan dan petunjuk kerja, mentaati prosedur dan instruksi secara tepat, sikap disiplin, tanggung jawab dalam melaksanakan pekerjaan, kebiasaan bekerja sama.

\section{KESIMPULAN DAN REKOMENDASI}

Berdasarkan hasil penelitian dan pembahasan dapat disimpulkan bahwa hambatan dalam penyelesaian tindak lanjut ini disebabkan oleh beberapa aspek internal, antara lain:

1. Sumber daya manusia, tidak dapat menyelesaikan sisa temuan hasil pemeriksaan BPK pada pemeriksaan kinerja atas kegiatan APIP secara tepat waktu disebabkan 3 (tiga) hal yaitu (a) kurangnya jumlah personil ASN APIP Inspektorat Kabupaten Barito Timur ketidaksesuaian latar belakang pendidikan personil ASN APIP, dan (c) kurangnya kerjasama tim (teamwork).

2. Kepemimpinan: (a) pimpinan belum menyusun rencana kerja penyelesaian TLHP-BPK pada pemeriksaan kinerja atas kegiatan APIP, membentuk tim khusus, 
mengkoordinir, mengontrol dan pengendalian, (b) tidak pernah melakukan rapat khusus membahas temuan BPK atas penyelesaian TLHP-BPK atas pemeriksaan kinerja APIP, (c) tidak ada pembentukan tim khusus yang menangani penyelesaian TLHP-BPK atas pemeriksaan kinerja APIP, (d) tidak adanya instruksi dari pimpinan untuk penyelesaian TLHP-BPK atas pemeriksaan kinerja APIP.

3. Lingkungan kerja, kondisi lingkungan kerja pada Inspektorat Kabupaten Barito Timur belum sepenuhnya memadai guna menunjang pelaksanaan kinerja yang baik. Lingkungan kerja non fisik, adanya budaya kerja yang belum optimal mendorong penyelesaian tindak lanjut. Sedangkan lingkungan kerja fisik, seperti tersedianya sarana dan fasilitas juga masih terbatas.

Berdasarkan hasil penelitian, maka peneliti merekomendasikan:

1. Hasil penelitian menunjukkan bahwa jumlah personil ASN APIP Inspektorat Kabupaten Barito Timur masih kurang, sehingga disarankan menambah personil ASN APIP Inspektorat Kabupaten Barito Timur dalam mendukung beban kerja organisasi Inspektorat dalam melaksanakan tugas-tugas pengawasan. Penambahan personil juga harus diikuti dengan peningkatan kapabilitas sumber daya APIP dengan pendidikan dan pelatihan pengawasan sehingga dalam melaksanakan tugas pengawasan dapat terlaksana sesuai dengan tujuan organisasi.

2. Kepemimpinan diharapkan memotivasi bawahan secara berjenjang, membuat perencanaan penyelesaian tindak lanjut serta melakukan pembinaan dan mengembangkan inovasi serta menciptakan lingkungan kerja untuk mendukung penyelesaian sisa temuan yang harus ditindaklanjuti.

3. Agar menambah alokasi dana khususnya untuk pengadaan sarana dan fasilitas dalam melengkapi pelaksanaan proses pekerjaan di Inspektorat Kabupaten Barito Timur sehingga dapat tercipta kenyamanan dalam bekerja.

\section{DAFTAR PUSTAKA}

Anaroga, \& Panji. (2004). Psikologi Kepemimpinan. Semarang: CV Rineka Cipta. Atmosoeprapto, K. (2002). Menuju SDM Berdaya-Dengan Kepemimpinan Efektif dan Manajemen Efisien. Jakarta: PT.Elex Media Komputindo.

Badu, S. Q., \& Djafri, N. (2017). Kepemimpinan dan Perilaku Organisasi. Gorontalo: Ideas Publishing.

BPK-RI. (2013). Laporan Hasil Pemeriksaan Kinerja atas kegiatan APIP pada Pemerintah Kabupaten Barito Timur. Palangkaraya.

BPK-RI. (2018). Pemantauan Tindak Lanjut Hasil Pemeriksaan. Palangkaraya: BPK Perwakilan Provinsi Kalimantan tengah.

Bungin, B. (2015). Penelitian Kualitatif. Jakarta: PRENADA MEDIA GROUP.

CF.Rauch, \& Behling, O. (1984). Functionalism:Basis for Alternative Approach to the Study of Leadership. New York: Pergamon Press.

Effendy, U. (2011). Asas Manajemen. Jakarta: PT Raja Grafindo.

Jensen, M. C., \& Meckling, H. W. (1976). Theory of The Firm: Managerial Behavior, Agency Cost, and Ownership Structure. Jurnal of Financial Economics, Vol. 3, No. 4, Octobe, 305-360

Halim, A., \& Abdullah, S. (2006). Hubungan dan Masalah Keagenan di Pemerintah Daerah. Jurnal Akuntansi Pemerintahan Volume 2, Nomor 1, 53-64.

Harinurhady, A., Rifa'i, A., \& Alamsyah. (2017). AnalisisPenyelesaian Tindak Lanjut Hasil Pemeriksaan Auditor Inspektorat Kabupaten Sumbawa Barat. Jurnal Economia, Volume 13, Nomor 1, 95-105.

Herbert, L. (2005). Auditing the Performance of Management. Belmont. California: Lifetime Learning Publication.

Jacobs, T., \& Jaques, E. (1990). Militery Executive Leadership. Amerika: Leadership Library.

Lusiana, Djamhuri, A., \& Prihatiningtias, \&. Y. (2017). Analisis Penyelesaian Tindak Lanjut Hasil Pemeriksaan. Jurnal Economia, Volume 13, Nomor 2, Oktober 2017, 171-190.

Mas'ud, F. (2004). Survai Diagnosis Organisasional Konsep dan Aplikasi. Semarang: Badan Penerbit Undip.

Murwanto, Rahmadi, Budiarso, A., \& Ramadhana, F. H. (2009). Audit Sektor Publik (Suatu Pengantar Bagi Pembangunan Akuntabilitas Instansi Pemerintah). Jakarta: Lembaga Pengkajian Keuangan Publik dan Akuntansi Pemerintah Badan Pendidikan 
dan Pelatihan Keuangan Departemen Keuangan RI.

Nawawi, H. (2001). Manajemen Sumber Daya Manusia. Jakarta: Bumi Aksara.

Nawawi, H. (2003). Manajemen Sumber Daya Manusia. Yogyakarta: UGM Press.

Notoatmodjo, \& Soekidjo. (2009). Pengembangan Sumber Daya Manusia. Jakarta: Rineka Cipta.

Pangoliu, R. R., Saerang, D., \& Manossoh, H. (2017). Analisis Kendala Penyelesaian Tindak Lanjut Hasil Pemeriksaan BPK pada Pemerintah Provinsi Gorontalo. Jurnal Riset Akuntansi Dan Auditing "Goodwill", 1-10.

Peraturan Daerah Kabupaten Barito Timur Nomor 3. (2016, Desember 7). Pembentukan dan Susunan Perangkat Daerah Kabupaten Barito Timur. Retrieved Juli 18, 2019

Rai, I. G. (2008). Audit Kinerja pada Sektor Publik. Jakarta: Penerbit Salemba Empat.

Robbins, P. S., \& Judge, T. A. (2007). Perilaku Organisasi. Jakarta: Salemba Empat.

Sedarmayanti. (2009). Sumberdaya Manusia dan Produktivitas Kerja. Bandung: CV Mandar Maju.

Suwatno, \& Priansa. (2011). Manajemen SDM dalam organisasi Publik dan Bisnis. Bandung: Alfabeta.

Tannebaum, \& Nassarik, W. \&. (1961). Materi Pelatihan Ketrampilan Manajerial SPMK. New York.

Thoha, \& Miftah. (2009). Kepemimpinan dalam Manajemen. Jakarta: Rajawali Press. 